ELORE (ISSN 1456-3010), vol. $14-2 / 2007$.

Julkaisija: Suomen Kansantietouden Tutkijain Seura ry.

[http://www.elore.fi/arkisto/2_07/hel2_07.pdf]

\title{
KIRJA-ARVIO: \\ Poloiset naiset ja Kartanoiden Valtiattaret \\ AKTIIVISINA
}

Lahtinen, Anu 2007: Sopeutuvat, neuvottelevat, kapinalliset. Naiset toimijoina

Flemingin sukupiirissä 1470-1620. Bibliotheca Historica 108. Helsinki: Suoma-

laisen Kirjallisuuden Seura. 241 sivua.

\section{$\underline{\text { Hilkka Helsti }}$}

Millaista oli 1500-luvun aatelisnaisten elämä? Toisin kuin isänsä, veljensä ja puolisonsa, nämä naiset eivät osallistuneet poliittisiin kokouksiin, eivät toimineet viroissa tai keränneet veroja, saati sitten johtaneet sotia. Anu Lahtinen kysyy tuoreessa historian alaan kuuluvassa väitöstutkimuksessaan, missä oli näitten naisten ensisijainen toimintapiiri ja mikä oli heidän asemansa vallan käyttäjinä, sen kohteina ja vastustajina.

Kysymykset ovat visaisia jo pelkästään lähdeaineiston saatavuuden kannalta. Lahtinen onkin tehnyt valtavan työn pöyhiessään arkistojen uumenista niukkasanaisia fragmentteja saadakseen edes jotain tietoa näiden naisten elämästä. Esimodernin ajan kirjallisesta aineistosta vain murto-osa on naisten tuottamaa, eikä arkistojen järjestämisessä ole huomioitu tämäntyyppisiä tutkimusnäkökulmia. Neulan etsiminen heinäsuovasta on kuitenkin tuottanut runsaasti löytöjä. Lähdeaineisto koostuu kirjeenvaihdosta, omaisuuden siirtoihin liittyvistä talousmuistiinpanoista ja muista asiakirjoista.

Aineiston analysointi on ollut haastavaa. Lahtinen huomauttaa, että lähteiden tulkinnat tapauksista saattavat usein olla ristiriitaisia. Tästäkin syystä tutkija on pitänyt hedelmällisempänä pohtia tekstien paljastamia arvoja ja tavoitteita kuin yrittää pitävästi todentaa tapahtumien yksityiskohtia. Lahtinen on kiinnittänyt paljon huomiota retoriikkaan ja argumentointiin ja nostanut aineistosta kulttuurisia jäsennyksiä, kuten ihanteita sukupuolen ja perheroolin mukaisesta toiminnasta. Tulkintojaan hän ryydittää kotimaisen ja kansainvälisen tutkijajoukon keskusteluilla sukupuolihistoriasta, esimodernin ajan naisista, sukulaisuudesta sekä aikakauden muutoslinjoista. Historiantutkimus lähestyy jälleen kerran kulttuurintutkimusta ja on senkin vuoksi etnologille kiintoisaa luettavaa. 


\section{POLOISET NAISET JA KARTANOIDEN VALTIATTARET AKTIIVISINA}

Anu Lahtisen tutkimuksen kohteena ovat erityisesti Flemingin mahtisuvun piirissä eläneet naiset. Flemingit asuivat Lounais-Suomen ja Ruotsin keskusalueilla, ja osalla heistä oli läheiset suhteet kuningashuoneeseen. Tutkimus fokusoituu naisten aktiiviseen toimintaan ja rooleihin tässä sukupiirissä. Aatelisnaisten elämä hahmottuu aviovaimoina, äiteinä, tyttärinä, sisarina ja suojatteina, jotka kommentoivat, tulkitsivat ja muokkasivat aikakautensa normeja. Esiin nostetaan niin naisten alisteinen asema kuin heidän ulottuvillaan olleet keinot asemansa parantamiseksi.

\section{Aviolitton JA PERHEEN MERKITYKSET}

Avioliitto oli norminmukainen ja odotettavissa oleva vaihe aatelisnaisen elämässä. Avioliitto ei merkinnyt pelkkää "parisuhdetta", vaan siitä seurasi huomattava ura suuren talouskokonaisuuden valtiattarena. Lisäksi rouvan keskeisiin tehtäviin kuului perillisten synnyttäminen ja vaaliminen. Loppujen lopuksi kartanon rouvan työala - ruoasta, vaatteista ja hoivasta huolehtiminen - oli samankaltainen kuin alempien luokkien naisilla. Toki kartanossa käytännön työt teki palveluskunta emännän toimiessa suunnittelu- ja työnjohtopuolella. Kartanon rouvat käyttivät emäntävaltaa, he valvoivat kartanon elämää ja jakelivat käskyjä erityisesti naispuolisille palvelijoille. Rouvien päätösvalta ja vastuu koski irtaimistoa ja heidän miehensä huolehtivat maaomaisuudesta. Vaikka myös vaimo saattoi olla maanomistaja, hallitsi aviomies hänen omaisuuttaan. Lahtinen kuitenkin huomauttaa, ettei aatelisnaisen ja hänen miehensä välinen työnjako ollut välttämättä todellisuudessa näin jyrkkä. Viralliset asiakirjalähteet kertovat ennen muuta päätöksistä ja ratkaisuista, eivät niinkään niiden valmisteluista tai neuvotteluista. Miehen edusmiehisyys esimerkiksi maanomistusasioissa saattoi kätkeä naisen toimijuuden. Kansanomaisesti tilanne on tavattu kiteyttää sanonnalla "mies on perheen pää ja nainen on kaula, joka sitä kääntää".

Aatelisnaiset toimivat usein miestensä neuvonantajina, koskipa kysymys sitten maanhankintaa tai suvun avioliittoneuvotteluja; heillä saattoi olla mielipiteitä myös politiikasta tai miestensä viranhoitoon liittyvistä asioista. Naisilla oli sosiaalisesti hyväksyttyä auktoriteettia, vaikka juridista valtaa puuttui. Leskinaiset olivat oikeustoimikelpoisia ja perheen omaisuuden hallitsijoita.

Tutkiessaan aatelisia äiteinä Anu Lahtinen kiinnittää huomionsa äidin arvovaltaan sekä arjessa että ihanteissa. Kirjeenvaihdossa, oikeusasiakirjoissa, talousmuistiinpanoissa ja anomuksissa viitataan retorisesti äidin olemukseen ja tämän velvollisuuksiin ja vastaavasti lapsen suhteeseen äitiinsä. Äidit ovat "rakkaita" ja lapset "kuuliaisia". Lahtinen toteaa, että kirjekaavoissa toistuvat ilmaisut eivät välttämättä välittäneet kirjoittajiensa sisimpiä tuntemuksia, mutta ne tuottivat ja uusintivat käsityksiä norminmukaisista suhteista. Rakkauden ja hierarkian vaatimukset kietoutuivat yhteen. Äidillä oli päätösvaltaa lasten avioliittoon, äiti saattoi päättää myös tyttärensä luovuttamisesta luostariin. Flemingit lähettivät tyttäriään ja huoltamiaan sukulaisneitoja etenkin Naantalin birgittalaisluostariin. Järjestelyllä turvattiin lapsen tulevaisuus - tai huolehdittiin suorasukaisesti toisille lapsille suuremmat perintöosuudet. Äidin ja 


\section{HiLKKa HELSTI}

lapsen suhteissa korostettiin vastavuoroisuutta. Lasten tuli palkita äidinrakkaus tottelevaisuudella ja vanhemmiten myös mahdollisella taloudellisella tuella; kiittämätön lapsi riskeerasi toisaalta perintönsäkin. Äitiys toi aatelisille, aivan kuten rahvaankin naisille perhepiirissä valtaa, joka lisääntyi vuosien myötä. Miniän sopi esiintyä nöyränä ja anoppi oli valtansa huipulla.

Äidillinen hoiva oli tarpeen sukupiirissä laajemminkin, niinpä nuoremman polven piti myös retorisesti osoittaa kunnioitusta ja palvelualttiutta suvun vanhemmille naisille. Anopin äitiä voitiin puhutella "rakkaaksi äitikullaksi", ja anoppi oli peräti "sydämeni kaikkein rakkain äitikulta". Nämä naiset saattoivat olla nuoremmille elintärkeitä huoltajia ja tukijoita, joten suhteiden ylläpito ja arvonanto oli tärkeää. Lapsia lähetettiin silloin tällöin oleskelemaan sukulaisten luo hoiva- tai kasvatustarkoituksessa. Kuten Lahtinen kirjoittaa, vanhemmat olivat tietoisia siitä, että kuolema saattoi temmata heidät koska vain pois lastensa luota. Oli syytä sosiaalistaa lapset pienestä pitäen suvun jäsenyyteen ja lujittaa suhteita eri keinoin.

Käsitteet "veljeys" ja "sisaruus" tuovat mielikuvan tasa-arvoisesta, lujasta ja vastavuoroisesta suhteesta sisarusten välillä ja metaforisesti muissakin suhteissa. Mielikuvat toistuivat myös Lahtisen tutkiman aikakauden aristokraattisessa retoriikassa. Sisarusten keskinäinen luottamus ja yhteistyö ei ollut kuitenkaan pelkkää retoriikkaa, vaan apu oli tavanomaista myös aatelisten arjessa, vaikkapa lasten kasvatuksessa. Avioliittoneuvotteluissa saatettiin kääntyä sisarusten puoleen ja pyytää heiltä neuvoja ja tukea. Tämä tasoitti vanhempien valtaa. Siskosten suhteissa näkyi jaettu elämänpiiri; sisaren ja veljen maailmat saattoivat poiketa suurestikin toisistaan sukupuolten erilaisen toiminta-alueen vuoksi. Molemminpuolinen lojaalisuus ei nojautunut kummassakaan tapauksessa satunnaisiin mieltymyksiin, vaan se oli normi, johon voitiin vedota virallisissakin yhteyksissä. Kuten elävässä elämässä välistä tapahtuu, ihmiset eivät toimi ihanteiden mukaan. Sisarukset saattoivat ajautua keskinäisiin valtataisteluihin sekä perintö- ja elatusriitoihin. Näin tapahtui esimerkiksi Klaus ja Filippa Flemingille. Filippa teki veljensä perinnöttömäksi useammastakin eri syystä. Pitkään sairastellut Filippa muun muassa katsoi, ettei hänen veljensä Klaus ollut muistanut häntä eikä pitänyt huolta hänestä sairauden aikana, joten hän ei ansainnut saada perintöjäkään. Filippa Fleming testamenttasi omaisuutensa tukijalleen kuningas Juhanalle, "poloiselle veljentyttärelleen” Anna Joakimsdotterille sekä kihlatulleen Knut Jönssonille.

Aateliset olivat monikerroksisesti hierarkkista väkeä. Hierarkioita loivat ikä, sukupuoli, siviilisääty, omaisuus ja suhde kuningashuoneeseen. Toisaalta aatelisten elämä näyttää olleen varsinaista peliä, jossa politiikka ja sotaretket, maaomaisuuksista ja perinnöistä riitely, järjestetyt sekä epäsäätyiset avioliitot ja aviottomat lapset siellä täällä sekoittuivat suloisesti hovielämän hohtoon. Hierarkiat olivat siis jatkuvassa liikkeessä ja niistä kamppailtiin. Flemingien arvovaltaisten sisäpiirien ulkopuolella oli heidän suojattejaan: alemmasta aatelista rekrytoituja luottopalvelijoita ja orpoja, mutta varteenotettavia sukulaisneitoja, "poloisia veljentyttäriä". Tällainen aatelisen hierarkian alimmilla portailla oleva nainen onnistui parhaiten hakemaan itselleen oikeutta etsimällä itselleen mahdollisimman vaikutusvaltaisen ja hyväntahtoisen miespuolisen suojelijan. "Poloisena" esiintynyt leski, orpo tai avioton tytär ei hyötynyt itsenäisyydestä vaan hyvästä suhteesta vallankäyttäjään. 


\section{POLOISET NAISET JA KARTANOIDEN VALTIATTARET AKTIIVISINA}

Tutkimuksessa problematisoidaan kiinnostavasti vallan olemusta ja sen paikantumista esimodernissa yhteiskunnassa. Loppuluvussa Anu Lahtinen tähdentää aatelisnaisten kätkettyä toimijuutta, joka jälkeenjääneissä asiakirjoissa piiloutuu usein holhoojan tai edusmiehen päätösten taakse. Naiset olivat aktiivisia toimijoita kotitaloudessa, perheen ja suvun piirissä. Siellä heillä oli vaikutusvaltaa ja oma työkenttänsä, kulloistenkin hierarkkisten järjestysten tarjoamissa puitteissa. Mielikuvaa työstä vapaista ylhäisönaisista ei siis voi liittää ainakaan Flemingeihin, jotka uurastivat täysillä perheensä, sukunsa ja kartanonsa puolesta.

\section{VÄRIKÄSTÄ TEKSTIÄ SOPIVISSA RAAMEISSA}

Lahtinen kuvaa ja analysoi sangen värikkäästi sukupiirin jäsenten mutkikkaita suhteita ja kohtaloita. Jännittävää aineistoa esitellään runsaasti, ja se tarjoaa sekä kiinnostavaa retoriikkaa että eloisia välähdyksiä elävästä elämästä. Tulkinnat ovat hienovireisiä ja hyvin perusteltuja, ja tutkimuksen juoni pysyy hyvin hallinnassa. Kirjan alkupuolella kuitenkin sain pienen sätkyn, kun kirjoittaja totesi, että" esimodernin ajan ibmiset ajattelivat aviollista rakkeautta bierarkkisena subteena" (s. 36; kursiivi H. H.). Ikään kuin olisi mahdollista, että kaikkki ihmiset olisivat yksissä tuumin päättäneet ajatella aviorakkaudesta juuri näin. Vaikka käsitys olisi käytetyssä aineistossa ollut hegemoninen, sen julistaminen täysin säröttömäksi on sentään liikaa. No, tämä taisi olla pikemmin muualta singahtanut sutkaus kuin painokas väite (tämäntyyppistä kirjoitustapaa olen nimittäin tavannut viljalti erinäisissä historiatieteen alaan kuuluvissa teoksissa). Lahtinen oivaltaa yleensä varsin hyvin aineistonsa luonteen ja kulttuurin moniäänisyyden ja kiinnittää huomiota siihenkin, mikä jää kirjeissä ja asiakirjoissa sanomatta. Hän tähdentää myös sitä, että ihmiset eivät aina toimineet vallitsevien ihanteiden mukaan, vaan suhtautuivat ihanteisiin esimerkiksi retorisina resursseina omaa hyötyä tavoitellessaan.

Anu Lahtinen kirjoittaa sujuvaa tekstiä, jota on ilo lukea. 214 sivuun on saatu mahtumaan sekä aineisto, tulkinnat että viitteet, mikä osoittaa mielestäni oivallista kykyä aiheen rajaukseen. Lisäksi kirja sisältää useita sukutauluja Fleming-suvun eri haaroista.

Monessa kohdin Anu Lahtinen arvelee, että aatelisnaisia koskevat pohdinnat voisi yhdistää myös muiden yhteiskuntaryhmien naisten elämään ja asemaan liittyviin keskusteluihin. Tässä hän osuu oikeaan. Kirjaa lukiessani ajattelin paljon omia aineistojani ja tutkimuksiani (naisten kirjeet, 1900-luvun alku, helsinkiläinen alempi keskiluokka) ja löysin kosolti yllättäviä, suorastaan hämmentäviä samankaltaisuuksia. Yhteistä oli muun muassa aktiivisuus, jolla naiset kunnostautuivat sukujen yhteyksien luojina ja ylläpitäjinä samoin kuin sukupiirin turvaverkkojen ahkerina kutojina. Ehkä sukulaisuus kulttuurisena järjestelmänä kantaa mukanaan sellaisia pitkän keston rakenteita, jotka voivat toimia niin kaksioissa kuin kartanoissakin.

Filosofian tohtori Hilkka Helsti on helsinkiläinen etnologi. 